\title{
Exploring the association among working memory, anxiety and Iranian EFL learners' listening comprehension
}

\author{
Ehsan Namaziandost ${ }^{1 *}$, Mitra Hafezian ${ }^{2}$ and Sajad Shafiee ${ }^{1}$
}

* Correspondence:
e.namazi75@yahoo.com
${ }^{1}$ Department of English, Faculty of
Humanities, Shahrekord Branch,
Islamic Azad University, Shahrekord,
Iran
Full list of author information is
available at the end of the article

available at the end of the article

\begin{abstract}
This study was intended to investigate the relationship between working memory, anxiety and Iranian EFL learners' listening comprehension. For the purpose of this study, 60 Iranian pre-intermediate EFL learners were selected among 80 students at a private language institute in Hamadan, Iran. They participated in a homogeneity test (Oxford Quick Placement Test) to determine their homogeneity level. At first, two working memory span tests was administered to participants. Moreover, foreign language listening anxiety questionnaire and listening comprehension tests were applied as another data gathering instruments. Pearson's Product moment correlation and one-way ANOVA were used to analyze the data. It was revealed that there was a strong, negative relationship between FL listening comprehension and listening anxiety. The study showed that a large number of the students experience high level of anxiety. Consequently, they were poor in their listening comprehension test implementation. Also, regarding working memory, it was found that working memory is an efficient and paramount prophesier for EFL listening comprehension. Learners with larger working memory capacity more likely have better abilities in listening. In addition, this study provides some pedagogical implications on EFL teaching.
\end{abstract}

Keywords: Anxiety, Listening comprehension, Foreign language listening, Foreign language, Listening anxiety, Working memory, Working memory span

\section{Introduction}

Listening is regarded as the most frequently-used language skill (Scarcella and Oxford 1992), plays a vital role in communication (Mendelsohn 1994), and "is probably the least explicit of the four language skills, thus, making it the most difficult skill to learn" (Vandergrift 2004). Listening in general, as described by Oxford (1993), is regarded as a complex problem-solving skill which is not only the recognition of sounds. Listening comprises understanding of words, phrases, clauses, sentences and connected discourse as well.

According to Buck (2001), for instance, listening comprehension is an active process of constructing meaning and this is performed by applying knowledge to the incoming sounds. Gary (1978) describes listening as an active process in which students' listening competence can be expanded by orally giving them non-verbal tasks to carry out. Lynch and Mendelsohn (2002) claim that listening comprehension consists of a variety

(c) The Author(s). 2018 Open Access This article is distributed under the terms of the Creative Commons Attribution 4.0 International License (http://creativecommons.org/licenses/by/4.0/), which permits unrestricted use, distribution, and reproduction in any medium, provided you give appropriate credit to the original author(s) and the source, provide a link to the Creative Commons license, and indicate if changes were made. 
of related processes comprising oral word recognition, perception of intonation patterns and interpretation of the relevance of what is being said to the current topic. Finally, for O'Malley and colleagues (1989), what makes listening an active process is that listeners focus on selected aspects of the aural input and construct meaning by relating what they hear to their prior knowledge.

A central issue in language learning is to find out what factors lead to variations in L2 performance among individuals. Recently, specifying what and how individual learner factors affect acquisition processes among L2 learners is of much interest to linguists in second language acquisition (SLA) domain. In general, some variables have been found to contribute to variations among the learners including affective factors, cognitive factors and personality-related ones (Kormos \& Sáfár, 2008). Despite the fact that the role of working memory capacity has been found significant in L1 acquisition by some researchers, (e.g., Daneman 1991; Daneman and Green 1986), it has not been much highlighted by L2 researchers as a cognitive factor. Hence, more attempts are required to investigate the impact of working memory on second language acquisition (Shahnazari 2013). In a broad sense, working memory is the human cognitive system responsible for the simultaneous and temporary processing and storage of information in the performance of cognitive activities such as comprehension, reasoning and learning (Baddeley 2003). The most important component in this model is the central executive or supervisory attentional system which is a limited capacity pool of general resources.

WM is assumed to play a critical role in listening processing by storing the result of the listeners' comprehension as they deal with the information in a spoken discourse at the same time. However, despite the importance of WM capacity, there has so far been limited understanding of the information processing and storage function of WM, especially in the listening process. Moreover, most of the previous research on the role of WM in L2 performance has overlooked the overlap between WM capacity and L2 linguistic and processing sub-skill variables.

Since working memory is implicated in second language acquisition domain, one question arising here is whether this factor can contribute to variations in L2 performance among individuals. In the area of L2 acquisition and use, not enough studies have been carried out to investigate L2 fluency, as an L2 performance variable, from a cognitive perspective. In other words, there is little research investigating the role of individual differences in working memory and L2 performance (Mota 2003).

An important variable associated with learning (including listening comprehension) is anxiety. In foreign language contexts, anxiety research has mostly focused on oral production (Kimura 2008). Moreover, Shift has occurred in receptive skills such as listening which is regarded as one of the most effective skills for foreign language learners (Vogely 1998). Listening is usually anxiety-inciting. Christenberry (2003) highlights the challenging nature of listening and states that it is regarded as an incredibly complicated subject to teach properly; therefore, listening is likely to be the source of anxiety.

Based on the extensive review of the literature of the field, little research seems to have been conducted to investigate the impact of working memory and anxiety on, or their relationship with listening comprehension of the learners especially in such EFL contexts as Iran. Thus, taking the above-mentioned significance of listening 
comprehension into account, considering the necessity to investigate the factors it might be related to or affected by, and taking into account the research gap which is felt to exist in this regard in such EFL contexts as that of the present study, it is deemed essential to find ways to develop learners' listening competence in foreign/second language acquisition by removing or reducing such stumbling blocks in the way as anxiety for instance and enhancing those factors which might contribute to the development of learners' listening comprehension.

\section{Literature review}

Theoretical background

Listening comprehension

The significance of listening skill was not recognized up to the early 1970s and it was through works done by such scholars as Asher (2000); Winitz (1981); and Krashen et al. (1984) that the role of listening as an important factor in easing language learning was paid attention (Vandergrift 2006). According to Scarcella and Oxford (1992), listening is regarded as the most frequently used language skill which is no longer ignored, neither in EFL classrooms nor in SLA research. Listening comprehension is regarded as a multifaceted active process which is affected by a multitude of factors including differentiating sounds, recognizing vocabulary and grammatical structure, understanding stress and intonation and relating it to the given context (Vandergrift, 1999). Vandergrift believes that listening is an integrative skill as it is typically the first skill that students develop which helps to acquire vocabulary and grammatical competence as well. Listening is considered as a cognitive process where the listener's auditory and/or visual receptors receive information in its sound form, and then the received information is filtered by the listener's short-term, working and long-term memory (Chamot 1995). Therefore, as stated by Vandergrift (2006), the listener chooses and interprets information to comprehend it.

\section{Listening anxiety}

Listening Anxiety One of the reasons that make foreign language learning a problematic area might be the fact that individual differences affect language learning process (Aydin 2009). As an affective factor which might be individually based, test-taking anxiety has recently been studied in different contexts. Although in the literature on foreign language leaning anxiety, learners have stated that speaking makes the most anxiety (Phillips 1992), within the researches of speaking anxiety, listening anxiety gradually began to emerge as a more problematic zone for learners. Vogely (1998) clearly stresses that listening anxiety is one of the most disregarded and probably the most debilitative sort of anxiety. Similarly, Krashen (as cited in Young 1992) maintains even though speaking is quoted as the most anxiety-provoking skill, listening comprehension is also extremely anxiety-inciting leading to incomprehensibility. Also, MacIntyre (1995) states, L2 listeners are anxious about mis/non-understanding and also worry about embarrassing results.

Several studies have been done on listening anxiety in foreign language contexts. For instance, Kim (2000a, b) investigated the association between listening anxiety and foreign language listening comprehension of Korean EFL students. Two hundred and 
fifty-three EFL learners participated in the study, among whom 20 students also took part in retrospective interviews. The results of correlation analyses showed that listening anxiety had a statistically significant association to both listening proficiency and foreign language anxiety. Furthermore, the results of multiple regression analysis revealed that students lack of confidence in foreign language listening was a better predictor of listening proficiency. A significant relationship was also found between listening anxiety and two background factors, namely, studying in private institutes and university major.

Elkhafaifi (2005) found that learners anxiety varied according to their level of ability in foreign language listening. He investigated the relationship between listening comprehension and anxiety in an Arabic language classroom. The results of his study revealed that the learners who suffered higher levels of foreign language learning anxiety were also found to have higher levels of listening anxiety. The findings also indicated that both foreign language learning anxiety and listening anxiety had a reverse correlation with participants' listening comprehension. Regarding two types of anxiety among students of first-, second-, and third-year Arabic, he found that students in third-year Arabic reported significantly lower levels of both types of anxiety than did their counterparts in the first year.

Moreover, some studies have explored the relationship between listening proficiency and listening anxiety. Aneiro (1989) found that her students' apprehension was mostly affected by their listening proficiency level. That is, Aneiro found a significant association between students' low anxiety and their high listening comprehension, which suggests that applying affective strategies to manage and control anxiety might enhance and facilitate listening comprehension. Other studies such as Elkhafaifi (2005) and Wang (2010) have also found that students' level of anxiety varies according to their level of listening ability.

In the same vein, Serraj and Noordin (2013) explored the possible relationship among Iranian EFL students foreign language anxiety, foreign language listening anxiety and their listening comprehension. Two hundred and ten Iranian EFL learners took part in their study. The results showed that there was a reverse correlation between foreign language listening anxiety and listening comprehension and also a statistically negative association between foreign language anxiety and listening comprehension, while foreign language anxiety and foreign language listening anxiety enjoyed a significant positive relationship. In addition, the results revealed that the impact of foreign language listening anxiety on Iranian learners listening comprehension skill was considerably more problematic. Regarding the sources of listening anxiety, Gonen (2009) believes that students might feel anxious whilst listening in the target language due to several reasons including the authenticity of the listening material, ambiguity of the listening text and environmental causes such as noise and vagueness. Other variables such as the difficulty level and nature of speech, lack of clarity and visual support as well as repetition might be involved in the issue as stated by Vogely (1998).

\section{Working memory}

Working memory is the small amount of information that can be held in mind and used in the execution of cognitive tasks, in contrast with long-term memory, the vast 
amount of information saved in one's life. Working memory is one of the most widely-used terms in psychology. It has often been connected or related to intelligence, information processing, executive function, comprehension, problem-solving, and learning, in people ranging from infancy to old age and in all sorts of animals Cowan (2014). This concept is so omnipresent in the field that it requires careful examination both historically and in terms of definition, to establish its key characteristics and boundaries.

Working memory involves the ability to keep information active in your mind for a short time $(2-3 \mathrm{~s})$ to be able to use it for further processing. Working memory is a temporary storage system and is vital for many day-to-day tasks (e.g. following instructions, responding in conversations, listening and reading comprehension, organization).

To fully understand the meaning of working memory, it is necessary to assess the strength of evidence for three types of memory: long-term memory, short-term memory, and working memory. Long-term memory is a vast store of knowledge and a record of prior events, and it exists according to all theoretical views; it would be difficult to deny that each normal person has at his or her command a rich, although not flawless or complete, set of long-term memories. Short-term memory is related to the primary memory of James (1890) and is a term that Broadbent (1958) and Atkinson and Shiffrin (1968) used in slightly different ways. Like Atkinson and Shiffrin, I take it to reflect faculties of the human mind that can hold a limited amount of information in a very accessible state temporarily. One difference between the term "short-term memory" and the term "primary memory" is that the latter might be considered to be more restricted. It is possible that not every temporarily accessible idea is, or even was, in conscious awareness Cowan (2014). For example, by this conception, if you are speaking to a person with a foreign accent and inadvertently alter your speech to match the foreign speaker's accent, you are influenced by what was until that point an unconscious (and therefore uncontrollable) aspect of your short-term memory. One might relate short-term memory to a pattern of neural firing that represents a particular idea and one might consider the idea to be in short-term memory only when the firing pattern, or cell assembly, is active (Hebb 1949). The individual might or might not be aware of the idea during that period of activation.

Working memory is not completely distinct from short-term memory. It is a term that was used by Miller et al. (1960) to refer to memory as it is used to plan and carry out behavior. One relies on working memory to retain the partial results while solving an arithmetic problem without paper, to combine the premises in a lengthy rhetorical argument, or to bake a cake without making the unfortunate mistake of adding the same ingredient twice. (Your working memory would have been more heavily taxed while reading the previous sentence if I had saved the phrase "one relies on working memory" until the end of the sentence, which I did in within my first draft of that sentence; working memory thus affects good writing) Cowan (2014). The term "working memory" became much more dominant in the field after Baddeley and Hitch (1974a, b) demonstrated that a single module could not account for all kinds of temporary memory. Their thinking led to an influential model (Baddeley 1986) in which verbal-phonological and visual-spatial representations were held separately, and were managed and manipulated with the help of attention-related processes, termed the central executive. 


\section{Working memory and EFL listening comprehension}

From an information-processing point of view, comprehension is subject to human memory capacity. In language comprehension, human working memory performs two functions: storage of information for later retrieval, and processing (Just and Carpenter 1987, 1992). One impressive study carried out by Ando et al. (1992), investigates the role of a larger working memory capacity in SLA. The result of the study shows that among various cognitive and personality factors, these children's working memory span in the first language (L1) before the English instruction can efficiently predict their performance in the second language $(r=.60)$ after the instruction.

Provided that working memory plays a crucial role in EFL language comprehension, it may also be important in EFL listening comprehension, according to Wu (1998), when task demands are high, due to storage and processing needs, the computation will slow down, and thus some partial results from working memory processing may be forgotten. This may account for the fact that EFL listeners often seem to be able to hear everything, but either forget what they have heard easily or cannot process what they have heard into meaning relationships. Accordingly, EFL listening comprehension depends on the storage and processing of information by the mind. Therefore, working memory may influence EFL listening co m prehension.

\section{The theories and studies on working memory}

In general, WM is defined as a system involving two functions: storage and the processing of input. Such a system has at least four major characteristics. It is temporary, limited in capacity, active, and complex (Baddeley 1986; Baddeley and Hitch 1974a, b; Daneman \& Blennerhassett, 1984; Engle, 2010; Fontanini \& Tomitch, 2009). In the present study, Baddeley and Hitch (1974a, b) model of working memory is adopted, as it is the most inferential one (Shanshan \& Tongshun, 2007). In this model, WM refers to a limited capacity system as the temporary storage and manipulation of input that is necessary for complex tasks such as comprehension and planning. In the past few years, some empirical studies have been conducted suggesting the role of working memory in L2 skills development. Among others, Gu and Wang (2007) conducted an empirical study to investigate the role of executive working memory (EWM) in the listening process and its relationship with listening comprehension scores among Chinese EFL learners $(N=59)$ at the university level. The results suggested that EWM was an effective predictor of the participants' listening comprehension performance.

The concept of working memory originally put forward by Baddeley and Hitch (1974a, b), and then improved in 1986, refers to the memory system used for the temporary holding and manipulation of information during the performance of a range of cognitive tasks such as comprehension, learning, and reasoning. The most influential model of working memory was proposed by Baddeley and Hitch (1974a, b), and then revised by Baddeley (1986 \& 1992). The major feature of this model is that working memory is conceived as a multi-component system consisting of three main components, i.e., the central executive the phonological loop and the visual-spatial sketchpad (Baddeley 1986).

The concept indicates that working memory has a limited capacity when dealing with high level cognitive tasks. The working memory capacity according to Engle (2001), 
refers to mechanisms that account for the co variation between a variety of working memory tasks, on the one hand. There are three tasks that have been frequently used to measure working memory capacity: reading span, operation span and counting span tasks. Engle (2001) demonstrates that these tasks clearly reveal some fundamental aspect of cognition. Scores on these tasks can predict a range of cognitive functions. Meanwhile plenty of investigation concerns the relationship between measures of working memory and measures of higher level cognitive skills and abilities (Engle, Cantor, \& Carullo 1992; Dane man \& Carpenter 1980; Just \& Carpenter 1987, 1992; Turner \& Engle, 1986, 1989). It can be universally accepted that working memory is a general memory system which plays a role in a wide variety of cognitive tasks.

Soodmand Afshar and Hamzavi (2014) investigated the relationship among reflective thinking, listening anxiety, and listening comprehension of Iranian EFL learners with regard to their proficiency level. To this end, 223 (106 intermediate and 117 advanced) adult male and female Iranian EFL learners from a private language institute took part in the study by completing the Reflective Thinking Questionnaire (RTQ) developed by Kember et al. (2000), the Foreign Language Listening Anxiety Scale (FLLAS) developed by Kim (2000a, b) and a listening comprehension test selected from the listening part of IELTS. Using factor analysis and Chronbach's Alpha, the questionnaires were revalidated and their reliability was re-estimated. The results of Pearson product moment correlations indicated there was a statistically significant: (a) positive association between reflective thinking and listening comprehension, (b) reverse correlation between listening anxiety and listening comprehension, and (c) reverse relationship between reflective thinking and listening anxiety of Iranian EFL learners. Furthermore, the results of multiple regression analysis indicated listening anxiety, compared to reflective thinking, was a significantly stronger predictor of listening comprehension. Additionally, the results of MANOVA revealed there was a significant difference between intermediate and advanced EFL learners with respect to their reflective thinking and listening anxiety. In the light of the findings of the study, foreign language education policy makers in general and EFL teachers in particular are thus recommended to introduce ways to enhance reflective thinking of the students and decrease their listening anxiety if they are to improve their listening comprehension.

\section{Research questions}

This study tries to answer the following question:

1. Is there any statistically significant relationship between Iranian EFL learners' working memory and their listening comprehension?

2. Is there any statistically significant relationship between Iranian EFL learners' anxiety and their listening comprehension?

\section{Methodology}

\section{Participants}

The participants of this study were 60 Iranian pre-intermediate English students who were selected among 80 students at a private language institute, Hamadan, Iran. The participants' age range is from 19 to 24 . They have been studying English as a foreign 
language for at least 6 years. Their level of English language proficiency was determined on the basis of their scores on the Oxford Quick Placement Test (OQPT). Only male students were participated in the current study. The participants' first language was Persian and they were selected based on non-random sampling method; based on their scores in OQPT.

\section{Instrumentation}

\section{Oxford quick placement test}

The first instrument which was utilized in the present study to homogenize the participants was a proficiency test. This test was the OQPT which was answered by all the participants of the current study. It helped the researcher to choose the pre-intermediate students. This test is consisted of 60 items which was developed by Oxford University Press and University of Cambridge Local Examinations Syndicate. The test has been validated in 20 countries by more than 6000 students and its reliability has reached 0.90 (Geranpayeh, 2003). This test has 60 multiple-choice items and based on it the learners whose scores are 0 to 10 are beginners; the leaners whose scores are 11 to 17 are considered as breakthrough; the learners whose scores are 18 to 29 are elementary; those learners whose scores are 30 to 39 are pre-intermediate; the students whose scores are 40 to 47 are intermediate; the learners whose scores are 48 to 54 are considered as the advanced learners and those whose scores are 55 to 60 are very advanced learners. Based on the results of this test, 60 pre-intermediate students were selected as the target population of the current study.

\section{Foreign language listening anxiety scale}

The second instrument which was used in the current study was a questionnaire (Foreign Language Listening Anxiety Scale (FLLAS)) which was created by Kim (2000a, b). It comprised of 33 items followed by 5 answer alternatives in which the learners were asked to show the degree of agreement or disagreement about their FL listening anxiety by circling choice numbers ranging from 1 to 5 , and demonstrate whether they 'strongly disagree', 'disagree,' 'neither agree nor disagree, 'agree' or 'strongly agree' with the items of the questionnaire on a 5-point Likert type scale when it portrays their listening comprehension anxiety. The objective of the questionnaire was to check the learners' level of FL listening comprehension anxiety while performing or working on listening exercises or assignments.

So as to enable the students answer the items in the questionnaire effortlessly or to eschew absence of data because of language hardness, it was translated into the students' mother tongue or native language (Persian (students' mother tongue) before regulating it to the subjects. Indeed, it is standard to permit second language students to react in their native language in depicting their learning systems (O'Malley \& Chamot, 1990). It is additionally practical for EFL learners.

Although the translated exemplar of the questionnaire was performed to the subjects, endeavors were still made to make everything explicit to them while they were fulfilling the questionnaire. Firstly, the goal of the questionnaire was elucidated to them orally, and the process for finishing it were clarified to them. Secondly, every item was perused out and its idea was quickly clarified as the respondents were filling in the survey. 
Consequently, they did not have much trouble of understanding the items and functioned as fast as they could to finish the questionnaire. Furthermore, in this study, the subjects working memory capacity was measured by a modified listening span test developed by Daneman and Carpenter (1980).

\section{Listening comprehension test}

The third instrument utilized in this study was the Listening Comprehension Test. It was utilized to recognize the qualities and shortcomings of learners' FL listening comprehension skills. The test comprised of 33 items; and it had 5parts. These incorporate recognizing positive and negative thoughts or explanations specified in the listening content, multiple choice items, and communicating creator's thoughts, clarifying the importance of words as they are utilized as a part of the content, and replying comprehension questions.

\section{Working memory span (WMS) test}

The Working Memory Span test includes two parts: A Listening Span Test and a Listening Comprehension Test. Both parts were taken together as two related parts of the WMS test.

\section{Data collection procedure}

To conduct the present study, the researcher attended the above-mentioned institute and give OQPT to 80 English students to determine their level of English proficiency. The researcher selected 60 pre-intermediate students. The teacher was cooperating with the researcher in the same private institute. The teacher gave important remarks on the previously mentioned information accumulation instruments. Notwithstanding, the last remarks were given by the researcher. After getting the fundamental remarks, the researcher rolled out a few improvements and amended vague things previously overseeing the devices for the last investigation in order to maintain a strategic distance from uncertainty with respect to the students. Next, the translated adaptation of FLLAS was piloted on thirteen pre-intermediate students who were not the subjects of the investigation. These empowered the researcher to see whether the apparatuses were reasonable or not.

Listening comprehension test was offered at firs to the selected students before collecting data utilizing the other data collection methods. Prior to the implementation of the test, the subjects were given introduction that the test was a piece of their appraisal of English subject; and they were given codes like S1, S2, S3, - S40 relying upon the initial alphabet letter of their names. After listening comprehension test was carried out to the students. This was done before the other information gathering apparatuses to perceive the amount they feel tension while stepping through the exam. This was vital for the understudies to finish or to fill the second instrument FLLAS poll to choose their agreement or disagreement about the items with respect to listening test. FLLAS survey was utilized to distinguish the level of the students' agreement or disagreement with the proclamations in the questionnaire towards their listening comprehension abilities. Moreover, participants' WM was measured through Working Memory Span (WMS) Test. 


\section{Data analysis procedure}

The collected data through the aforesaid procedures will be analyzed and interpreted according to the objectives of the study. Therefore, the data obtained from the listening comprehension test and FLLAS questionnaire were analyzed quantitatively through applying the latest SPSS version windows 25. Keeping in mind the end goal to examine the information assembled through listening comprehension test and FLLAS poll and to explore the connection between FL listening comprehension and listening anxiety, Pearson's Product Moment of Correlation was utilized. Connection investigation is utilized to depict the strength and direction of the linear connection between two variables. Moreover, to analyze the data gathered through listening comprehension test and FLLAS questionnaire, one-way analysis of variance (ANOVA) was run to show the probable differences among the listening abilities of students with low, average, and high level of anxiety. In addition, Pearson correlation co-efficient was used to analyze the data to reveal if there is any association between working memory and listening comprehension.

\section{Results and discussion}

The primary goal of the current study was to specify the relationship between listening comprehension, working memory, and foreign language listening anxiety. To fulfill, the listening comprehension test was performed and the papers were corrected. Afterwards, scores for the students' improvement were given based the marking system of Education Ministry of Iran for high school students' promotion which is also applicable for institutes. Pursuant to the Ministry, the marking system is offered as follows:

»19-20 Excellent

»17-19 Very Good

»15-17 Good

»13-14 Fair

Below 13 Poor

Table 1 indicates that $1(2 \%)$ of students were excellent. Only 3(8\%) of the students got very good results (17-19). The other $8(20 \%)$ of the students scored good mark (15-17). Another 13(32\%) of the students obtained fair outcome (13-14), and the final group 15(38\%) of the students scored poor mark (below 50\%). The mentioned students' test improvements divulged that approximately half of the students were poor (scored below 50\%). This implies that a large portion of the students had problem of listening and comprehending listening text, and fizzled doing or finishing listening comprehension exercises. This outcome demonstrated that the learners were poor in their listening comprehension abilities as a result of various

Table 1 Frequency of the participants' Listening Test Achievement

\begin{tabular}{llc}
\hline Grading System & Frequency & Percent \\
\hline $19-20$ Excellent & 1 & 2 \\
$17-19$ Very Good & 3 & 8 \\
$15-17$ Good & 8 & 20 \\
$13-14$ Fair & 13 & 32 \\
Below 13 Poor & 15 & 38 \\
Total & 40 & 100 \\
\hline
\end{tabular}


reasons. On the other hand, since the stamping framework set by the Ministry of Education contains 5(five) scales, the researcher endeavored to transform it into 3(three) scales for gathering the students into low, average, and high achievers based on their listening test accomplishment. To do so, the students who got the mark 17-20 in the grading system were considered as high achievers. The other group that scored 15-17 in the grading system was taken as average achievers. The remaining group who scored the mark below 14 (13-14 fair, and below 13 poor in the grading system) was taken as low achievers Table 2.

This table demonstrates that only $4(10 \%)$ were high achievers (scored 17-20). The other group of students $8(20 \%)$ was average achievers (scored 15-17). The rest of most of the students $28(70 \%)$ who earned the mark underneath 14 were low achievers. The quantity of these students was more prominent than the quantity of both high and normal achiever students; much more noteworthy than twice of them. This implies most of the subjects experience difficulty of listening and understanding listening content due to different reasons.

Next to the listening test, the FLLAS survey was managed to all example subjects. They all finished it suitably and restored the papers. After the papers were restored, the aggregate of each understudy's FL listening anxiety outcome was figured out. Next, contingent upon their anxiety result, they were ordered in to three groups namely: low anxious students, average anxious students, and high anxious students. Therefore, first, the minimum and the maximum anxiety outcome were distinguished. Since the FLLAS comprised of 33 items in the questionnaire and the score of per item ranged from 1 to 5 points, the potential mark of every student's anxiety should go from33 to 165 points; and lower scores show lower levels of listening anxiety while higher scores mean higher levels of listening anxiety. Then, the range of the minimum and the maximum anxiety result was computed $(165-33=132)$. Then, the earned finding was classified in to three equipollent groups. Consequently, the first group who scored between the ranges 33-77 was considered as low anxious students. The second group (78-121) as average anxious students and the last group (above 122) was considered as high anxious students.

As illustrated in Table 3, those students who experienced high levels of anxiety $18(45 \%)$ are more than those with average anxiety $13(33 \%)$ and near to twice the number of students with low levels of FL listening anxiety. Out of 40 students, only $9(22 \%)$ had low levels of FL listening anxiety.

So, investigating the degree of the subjects' FL listening anxiety, descriptive statistics of FLLAS questionnaire was earned.

Table 4 shows the mean $M=101.0500$ and Std. Deviation $S D=20.82891$. The result revealed that the students have experienced high listening anxiety, which reverberate that within the procedure of listening comprehension, the students become anxious

Table 2 Participants' classification based on achievement

\begin{tabular}{lll}
\hline Levels & Frequency & Percent \\
\hline $17-20$ High & 4 & 10 \\
15-17 Average & 8 & 20 \\
Below 14 Low & 28 & 70 \\
Total & 40 & 100 \\
\hline
\end{tabular}


Table 3 Distribution of the participants' FL Listening Anxiety Levels

\begin{tabular}{llll}
\hline Anxiety levels & Anxiety Score & No. of students & Percent \\
\hline Low anxiety & $33-77$ & 9 & 22 \\
Average anxiety & $78-121$ & 13 & 33 \\
High anxiety & $122-165$ & 18 & 45 \\
Total & & 40 & 100 \\
\hline
\end{tabular}

easily. This event is maybe due to the emotional condition of the listeners. Listeners are in a relatively passive position in comparison with other two skills of speaking and writing. Furthermore, discourse signals are quick, nonstop and temporary, so students dependably take an overwhelming mental weight and need to focus the mind totally.

In the examination of FLLA, 18(49.49\%) understudies picked "agree" when responding the item "I get nervous if a listening passage is read only once during English listening tests"; 17(46.46\%) students selected "agree" in the item "when a person speaks English very fast, I worry that I might not understand all of it"; however, 17(46.46\%) students select "strongly agree" in the item "I get worried when I have little time to think about what I hear in English." Thus, anxiety is ubiquitous and universal in EFL listening comprehension.

To check the relationship between listening comprehension and listening anxiety, Pearson's product of moment correlation was run.

As revealed in Table 5, there is a strong, negative correlation between FL listening comprehension and listening anxiety with $r=-.957$ and $p=.000<.05$. The negative correlation between the two variables (test score and listening anxiety) shows that as the students' FLA diminishes, their listening comprehension performance increases. In other words, when the students' FLA increases, their listening comprehension execution diminishes.

At the point when students accompany crosswise over new words and troublesome sentences, they become stressed and anxious, this in turn impacts the following content. Despite the fact that it appears that they are listening, indeed, they have subjugated. After a progression of horrible circles, they lose all enthusiasm for listening. Also, figuring procedure can be separated by higher uneasiness. The students with lower anxiety not exclusively can make a positive reaction quickly as indicated by the obtained information and relating cues, but also change thinking immediately when meet with obstruction; while students with higher anxiety whose thinking procedure is limited, cannot make a right judgment.

Analysis of the differences between low, average and high level anxiety achiever students was also checked. In order to see the differences in their listening test achievement, first an $\mathrm{F}$ value was calculated and checked for significance.

Based on Table 6, the calculated value of $\mathrm{F}$ is 98.986 which is higher than the value table 5.25 at $5 \%$ level with degree of freedom being variation Between Groups (V1 = 2,

Table 4 Descriptive Statistics of FLLAS Questionnaire

\begin{tabular}{llcccc}
\hline & $N$ & Minimum & Maximum & Mean & Std. Deviation \\
\hline FLLAS & 40 & 63.00 & 145.00 & 101.0500 & 20.82891 \\
Valid N (listwise) & 40 & & & & \\
\hline
\end{tabular}


Table 5 The relationship between Listening Test Achievement and FLLAS

\begin{tabular}{llll}
\hline Correlations & & & \\
\hline Variables & & Listening Anxiety & Test Scores \\
\hline Listening Anxiety & Pearson Correlation & 1 & $-.957^{\mathrm{a}}$ \\
& Sig. (2-tailed) & & .000 \\
& $\mathrm{~N}$ & 40 & 40 \\
Test Scores & Pearson Correlation & $-.957^{\mathrm{a}}$ & 1 \\
& Sig. (2-tailed) & .000 & \\
& $\mathrm{~N}$ & 40 & 40 \\
\hline
\end{tabular}

${ }^{a}$ Correlation is significant at the 0.01 level (2-tailed)

and variation Within Groups (V2 = 37). Therefore, it can be concluded that the test score was significantly different for the three (low, average, and high) FLLA levels (sig. $=.000)$.

In general, it can be said that students' foreign language listening anxiety is in opposite with their listening comprehension performance. It means that, when the students' foreign language listening anxiety increases, their listening comprehension performance decreases and vice versa. By and large, low anxious students are good achievers in their listening comprehension than average and high anxious students. However, average anxious students are a little bit better than high anxious achievers.

Moreover, in this study, in order to understand the relationship between working memory and listening comprehension, correlation analysis was used. The result demonstrated in Table 7.

As presented in Table 7, there is a high correlation between the two working memory spans $(r=0.871, p<0.01)$. It demonstrates that working memory is a pervasive mental resource that speakers of different languages will rely on.

To sum up, the major objective of the present study was to determine whether there was any relationship between foreign languages listening, working memory, and foreign language listening anxiety. The study showed that there was a negative correlation between the two variables (test score and listening anxiety), which reveals that as the students' foreign language listening anxiety reduces, their listening comprehension performance augments and vice versa. The results are congruent with the outcomes of the researchers carried out by Gonen (2009). This finding is also in line with the results of prior studies done by Kim (2000a, b), Elkhafaifi (2005), Kimura (2011) and Golchi (2012). The findings additionally showed that high anxiety interpolates with the processing of listening comprehension, and the stronger anxiety the students experience, the worse listening achievements they make.

Moreover, findings in the correlation analysis in Table $7(r=.871, p<0.01)$ are in line with with the outcome $(r=.874, p<0.01)$ of the study on the role of working memory in EFL listening comprehension administered by Wu (2002).

Table 6 Significance of Listening Test Achievement and FLLA Level

\begin{tabular}{lllcll}
\hline Source of variations & Sum of Squares & Df & Mean Square & F & Sig. \\
\hline Between Groups & 7312.212 & 2 & 3998.798 & 98.986 & .000 \\
Within Groups & 1549.368 & 37 & 41.458 & & \\
Total & 8861.580 & 39 & & & \\
\hline
\end{tabular}


Table 7 Correlation between working memory and listening comprehension

\begin{tabular}{lll}
\hline & L1 working memory capacity & L2 working memory capacity \\
\hline L1 working memory capacity & 1 & 0.871 \\
L2 working memory capacity & 0.871 & 1 \\
\hline
\end{tabular}

Therefore, regarding the function of working memory in listening comprehension process, it can be claimed that the comprehension of both written and spoken language depends on some form of working memory (Baddeley 1986). Working memory capacity may impact not only the length of the information provisionally accumulated in the short- term memory but also the process rapidity of probing for extant information in the long-term memory.

\section{Conclusion}

This study tried to investigate the association among working memory, anxiety and Iranian EFL learning listening comprehension. Regarding the relationship between FL listening comprehension and listening anxiety, Pearson's Moment of Correlation Coefficient showed that there was a strong, negative relationship between FL listening comprehension and listening anxiety with $\left(r=-.957, p=.000^{<} .05\right)$. With respect to the differences in the level of anxiety among low, average, and high achiever students, the study revealed that a large number of the students experience high level of anxiety. Due to this, they were poor in their listening comprehension test implementation. However, average anxious students were better than high anxious students but low anxious students were better than both average and high anxious students in their listening test improvement. The research made a combination of quantitative study and qualitative study. Regarding the reasons or sources of the subjects' FLLA, the information collected showed that the students do not feel assured and safe during listening comprehension activities. Also, with regard to working memory, it was found that working memory is an efficient and paramount prophesier for EFL listening comprehension. Learners with larger working memory capacity more likely have better abilities in listening. To conclude, L1 and L2 working memory spans have significant correlation.

The importance of the findings about the relationships between working memory, listening anxiety and listening comprehension lies not only in their contribution to the literature but also in their remarkable educational implications for instruction and assessment as well as curriculum development. The main implication of this study would be directed to educational policy makers, syllabus designers, and material developers for listening courses to deem working memory and listening anxiety as two crucial elements in both academic and future career success of EFL learners. Based on the findings of the present study, it also seems reasonable to suggest that EFL/ESL teachers try to employ educational practices and strategies that help learners have a better working memory and reduce their anxiety especially in dealing with such challenging tasks as listening.

The findings might further imply that Iranian EFL teachers should try to detect the potential sources of their students' listening anxiety and present some practical strategies likely to reduce the degree of listening anxiety among foreign language learners and generate a low-anxiety environment. It could also be suggested that the learners 
with poor WM ability and higher listening anxiety be identified and treated in order to increase their listening comprehension.

Moreover, EFL teachers are recommended to make students with other levels of language proficiency (i.e. elementary, intermediate, and upper-intermediate learners) conscious and utilize educational practices and strategies that assist learners in developing WM and in reducing their anxiety especially in handling such demanding skills as listening.

\section{Abbreviations}

EFL: English as a foreign language; FLLAS: Foreign Language Listening Anxiety Scale; OQPT: Oxford Quick Placement Test; WM: Working memory

\section{Acknowledgements}

Not applicable.

\section{Funding}

The study did not receive any funding.

\section{Availability of data and materials}

Please contact corresponding author for data requests.

\section{Authors' contributions}

All authors of the research had more or less equal contributions in the process of conception and design, acquisition of data, and analysis and interpretation of data. They have all been involved in revising the manuscript critically to the same extent. Both take public responsibility for the whole content. Both are equally accountable for all aspects of the work. All authors read and approved the final manuscript.

\section{Competing interests}

The authors declare that they have no competing interests.

\section{Publisher's Note}

Springer Nature remains neutral with regard to jurisdictional claims in published maps and institutional affiliations.

\section{Author details}

${ }^{1}$ Department of English, Faculty of Humanities, Shahrekord Branch, Islamic Azad University, Shahrekord, Iran.

${ }^{2}$ Department of English language, Bu-ali Sina University, Hamedan, Iran.

Received: 1 August 2018 Accepted: 22 October 2018

Published online: 06 November 2018

\section{References}

Ando, J., Fukunaga, N., Kurahashi, J., Suto, T., Nakano, T., \& Kage, M. (1992). A comparative study on the two EFL teaching methods: The communicative and the grammatical approach. Japanese Journal of Educational Psychology, 40, 247-256 (in Japanese).

Aneiro, S. (1989). The influence of receiver apprehension in foreign language learners on listening comprehension among Puerto Rican college students. Unpublished doctoral dissertation. New York, NY: New York University.

Asher, J. (2000). Learning another language through actions. Sky Oaks, CA: Sky Oaks Productions. Sixth Edition.

Atkinson, R. C., \& Shiffrin, R. M. (1968). Human memory: A proposed system and its control processes. In K. W. Spence \& J. T. Spence (Eds.), The psychology of learning and motivation: Advances in research and theory (Vol. 2, pp. 89-195). New York: Academic Press.

Aydin, S. (2009). Test anxiety among foreign language learners: A review of literature. Journal of Language and Linguistic Studies, 5(1), 127-137.

Baddeley, A. (2003). Working memory and language: An overview. Journal of Communication Disorders, 36(3), 189-208.

Baddeley, A. D. (1986). Oxford Psychology Series no. 11. Oxford: Clarendon Press.

Baddeley, A. D. (1992). Short-term phonological memory and long- term learning: A single case study. European Journal of Cognitive Psychology, 5, 129-148.

Baddeley, A. D., \& Hitch, G. (1974a). Working memory. In G. H. Bower (Ed.), The psychology of learning and motivation (Vol. 8, pp. 47-89). New York: Academic Press.

Baddeley, A. D., \& Hitch, G. J. (1974b). Working memory. The Psychology of Learning and Motivation, 8, 47-89.

Broadbent, D. E. (1958). Perception and communication. New York: Pergamon Press.

Buck, G. (2001). Assessing listening. Cambridge: Cambridge University Press.

Chamot, A. U. (1995). Learning strategies and listening comprehension. In D. J. Mendelsohn \& J. Rubin (Eds.), A guide for the teaching of second language listening (pp. 13-30). San Diego, CA: Dominie Press.

Christenberry, B. (2003). Listening comprehension in the foreign language classroom. Retrieved from http://langlab.uta.edu/ german/lana.rings/fall01gradstudents/2001 paperchristenberry.htm.

Cowan, N. (2014). Working memory underpins cognitive development, learning, and education. Educational Psychology Review, 26(2), 197-223. 
Daneman, M. (1991). Working memory as a predictor of verbal fluency. Journal of Psycholinguistic Research, 20(6), $445-464$.

Daneman, M., \& Blennerhassett, A. (1984). How to assess the listening comprehension skills of pre -readers. Journal of Educational Psychology, 76(6), 1372-1381.

Daneman, M., \& Carpenter, P. A. (1980). Individual differences in integrating information between and within sentences, Journal of Experimental Psychology: Learning, Memory, and Cognition, 19, 561-583. https://doi.org/10.1016/S0022$5371(80) 90312-6$

Daneman, M., \& Green, I. (1986). Individual differences in comprehending and producing words in context. Journal of Memory and Language, 25(1), 1-18.

Elkhafaifi, H. (2005). Listening comprehension and anxiety in the Arabic language classroom. The Modern Language Journal, $89,206-220$.

Engle, R. W. (2010). Role of working memory capacity in cognitive control. Current Anthropology, 51(1), 517-526.

Engle, R. W. (2001). What is working memory capacity? In H. L. Roediger III, J. S. Nairne, I. Neath, \& A. M. Surprenant (Eds.), Science conference series. The nature of remembering: Essays in honor of Robert G. Crowder (pp. 297-314). Washington, DC: American Psychological Association.

Engle, R. W., Cantor, J., \& Carullo, J. J. (1992). Individual differences in working memory and comprehension: A test of four hypotheses. Journal of Experimental Psychology, Learning, Memory, and Cognition, 18, 972-992.

Fontanini, F., \& Tomitch, L. B. (2009). Working memory capacity and L2 university students' comprehension of linear texts and hypertexts. International Journal of English Studies, 9(2), 1-18.

Gary, J. O. (1978). Why speak if you don't need to? The case for a listening approach to beginning foreign language learning. In Ritchie, W. (Ed.), Second language acquisition research: Issues and implications (pp. 185-199). New York:Academic Press.

Geranpayeh, A. (2003). A quick review of the English Quick Placement Test. Research Notes Quarterly, 12, 8-10.

Golchi, M. M. (2012). Listening anxiety and its relationship with listening strategy use and listening comprehension among Iranian IELTS learners. International Journal of English Linguistics, 2(4), 115-128.

Gonen, M. (2009). The relationship between FL listening anxiety and foreign language listening strategies: the case of Turkish EFL learners. Proceedings of the 5th WSEAS/IASME International Conference on Educational Technologies (EDUTE' 09).

Gu, S., \& Wang, T. (2007). Study on the relationship between working memory and EFL listening comprehension. CELEA Journal, 30, 46-56.

Hebb, D. O. (1949). Organization of Behavior. New York: Wiley.

James, W. (1890). The principles of psychology. New York: Henry Holt.

Just, M. A., \& Carpenter, P. A. (1987). The psychology of Reading and language comprehension (pp. 453-482). London: Allyn and Bacon, Inc.

Just, M. A., \& Carpenter, P. A. (1992). A capacity theory of co m prehension :Individual differences in working memory. Psychological Review, 99(1), 122-149.

Kember, D., Leung, D. Y. P., Jones, A., Loke, A. Y., McKay, J., Sinclair, K., \& Yeung, E. (2000). Development of a questionnaire to measure the level of reflective thinking. Assessment and Evaluation in Higher Education, 25(4), 382-395.

Kim, J. H. (2000a). Foreign language listening anxiety: A study of Korean students learning English. Unpublished doctoral dissertation. Austin, TE: University of Texas.

Kim, J. H. (2000b). Foreign language listening anxiety: A study of Korean students learning English. Unpublished doctoral dissertation. University of Texas, stAuin.

Kimura, H. (2008). Foreign language listening anxiety: Its dimensionality and group differences. JALT Journal, 30(2), $173-196$.

Kimura, H. (2011). A self-presentational perspective on foreign language listening anxiety. Unpublished Doctoral Dissertation. Philadelphia: Temple University.

Kormos, J., \& Sáfár, A. (2008). Phonological short term-memory, working memory and foreign language performance in intensive language learning. Bilingualism: Language and Cognition, 11, 261-271.

Krashen, S. D., Terrell, T. D., Ehrman, M. E., \& Herzog, M. (1984). A theoretical basis for teaching the receptive skills. Foreign Language Annals, 17(4), 261-275.

Lynch, T., \& Mendelsohn, D. (2002). Listening. In N. Schmitt (Ed.), An introduction to applied linguistics (pp. 193-210). London: Arnold.

Maclntyre, P. D. (1995). How does anxiety affect second language leaning? A reply to Sparks and Ganschow. Modern Language Journal, 79(1), 90-99.

Mendelsohn, D. J. (1994). Learning to listen: A strategy-based approach for the second-language learner. San Diego, CA: Dominie Press.

Miller, G. A., Galanter, E., \& Pribram, K. H. (1960). Plans and the structure of behavior. New York: Holt, Rinehart and Winston, Inc.

Mota, M. B. (2003). Working memory capacity and fluency, accuracy, complexity, and lexical density in L2 speech production. Fragmentos: Revista de Línguae Literatura Estrangeiras, 24, 69-104.

O'Malley, J. M., \& Chamot, A. U. (1990). Learning strategies in second language acquisition. Cambridge: Cambridge University Press.

O'Malley, J. M., Chamot, A. U., \& Küpper, L. (1989). Listening comprehension strategies in second language acquisition. Applied Linguistics, 10(4), 418-437.

Oxford, R. L. (1993). Research update on teaching L2 listening. System, 21(2), 205-211.

Phillips, E. M. (1992). The effects of language anxiety on students oral test performance and attitudes. The Modern Language Journal., 76(1), 14-26.

Scarcella, R. C., \& Oxford, R. L. (1992). The typstry of the language learning: The individual in the communicative classroom. Boston, MA: Heinle \& Heinle Publishers.

Serraj, S., \& Noordin, N. (2013). Relationship among Iranian EFL students' foreign language anxiety, foreign language listening anxiety and their listening comprehension. English Language Teaching, 6(5), 1-12.

Shahnazari, M. (2013). The development of a Persian reading span test for the measure of L1 Persian EFL learners' working memory capacity. Applied Research on English Language, 2(2), 107-116.

Shanshan, G., \& Tongshun, W. (2007). Study on the relationship between work ing memory and EFL listening comprehension. CELEA Journal, 30(6), 46-55. 
Soodmand Afshar, H., \& Hamzavi, R. (2014). The relationship among reflective thinking, listening anxiety and listening comprehension of Iranian EFL learners: Does proficiency make a difference? Issues in Language Teaching (ILT), 3(2), $237-261$. Turner, M. L., \& Engle, R. W. (1989). Is working memory capacity task - dependent? Journal of Memory and Language, 28, 127-154 Turner, M.L., \& Engle, R.W. (1986). Is working memory capacity task dependent? Journal of Memory \& Language, 28(2), 127-154. Vandergrift, L. (2004). Listening to learn or learning to listen? Annual Review of Applied Linguistics, 24(1), 3-25.

Vandergrift, L. (2006). Second language listening: Listening ability or language proficiency? The Modern Language Journal $90(1), 6-18$

Vandergrift, L. (1999). Facilitating Second Language Listening Comprehension: Acquiring Successful Strategies. ELT Journal 53/ 3: $168-176$.

Vogely, A. J. (1998). Listening comprehension anxiety: Students' reported sources and solutions. Foreign Language Annals, $31(1), 67-80$.

Wang, S. (2010). An experimental study of Chinese English major students' listening anxiety of classroom learning activity at the university level. Journal of Language Teaching and Research, 1(5), 562-568.

Winitz. H., (1981). Input considerations in the comprehension of first and second languages. H. Winitiz. Native language and foreign language acquisition. N.Y. Academy of Sciences 379, 296308.

Wu, Y. (1998). What do tests of listening comprehension test? - A retrospection study of EFL test takers performing a multiple-choice task. Language Testing, 15 (1) 21-44.

Wu, H. (2002). The Influence of Working Memory Differences on Listening Comprehension. Graduate thesis of the PLA School of Foreign Languages. China Excellent Masters Full-tex database.

Young, D. J. (1992). Language anxiety from the foreign language specialists' perspective: Interviews with Krashen, Omaggio, Hadley, Terrell, and Rardin. Foreign Language Annals, 25(2), 157-172.

\section{Submit your manuscript to a SpringerOpen ${ }^{\circ}$} journal and benefit from:

- Convenient online submission

- Rigorous peer review

- Open access: articles freely available online

- High visibility within the field

Retaining the copyright to your article

Submit your next manuscript at $>$ springeropen.com 